\section{World Health Organization and the search for accountability: a critical analysis of the new framework of engagement with non-state actors}

\author{
A Organização Mundial da Saúde e a procura \\ da responsabilização: uma análise crítica da \\ estrutura de colaboração com intervenientes \\ não estatais
}

La Organización Mundial de la Salud y la búsqueda de la rendición de cuentas: un análisis crítico del nuevo marco de colaboración con los actores no estatales

\begin{abstract}
The article probes the origins and content of the Framework of Engagement with Non-State Actors (FENSA) of the World Health Organization (WHO), approved on May 28, 2016, at the 69th World Health Assembly, which established different rules of collaboration to four categories of actors: nongovernmental organizations (NGOs), private sector entities, philanthropic foundations, and academic institutions. Applying the findings of International Legal Theory and based on extensive documentary research, we sought to determine whether FENSA is an appropriate accountability mechanism according to four functions of accountability: constitutional, democratic, epistemic, and populist. The article concludes that there is a risk of the prevalence of the populist function at the expense of the accountability potential that could result from the better use of the other three accountability functions.
\end{abstract}

Global Health; Legal Liability; International Law
Danielle Hanna Rached 1

Deisy de Freitas Lima Ventura 1,2

\author{
Correspondence \\ D. F. L. Ventura \\ Faculdade de Saúde Pública, Universidade de São Paulo. \\ Av. Dr. Arnaldo 715, São Paulo, SP 01246-904, Brasil. \\ deisyflv@gmail.com \\ 1 Instituto de Relações Internacionais, Universidade de São \\ Paulo, São Paulo, Brasil. \\ 2 Faculdade de Saúde Pública, Universidade de São Paulo \\ São Paulo, Brasil.
}




\section{Introduction}

The World Health Organization (WHO) is the "directing and coordinating authority on international health work", according to its own constitution 1 . WHO is financed by a mix of assessed contributions provided by Member States and voluntary contributions provided by both State and non-State actors. By 1990 , voluntary contributions had increased to $54 \%$ of total funds and now make up almost $80 \%$ of WHO's total income (US\$ 4.4 billion for 2016-2017) 2, a modest budget for the functions that the Organization has to exercise. WHO's top 20 contributors provide nearly $80 \%$ of the total financing among them, Bill and Melinda Gates Foundation, Rotary International and Bloomberg Family Foundation ${ }^{3}$-, which motivated the Director-General, Margaret Chan, to say: "A broader base of contributors would make this Organization more genuinely owned by its Member States" 4. She somehow agreed with those who believe that $\mathrm{WHO}$ actions and priorities are no longer the result of the consensus of the world's people but top down decision making from wealthy philanthropists 5 .

In 2011, WHO initiated a reform process in the middle of a severe budget crisis. In our opinion, the main objectives of this process, which are still far from being achieved, are the search for financing and the recovery of WHO's reputation. WHO is caught in a vicious cycle: its chronic underfunding, caused by Member States and private donors lack of confidence in the organization, creates an increasingly unsatisfactory performance, which only aggravates its lack of confidence ${ }^{6}$. On top of that, WHO was heavily criticized during the AH1N1 pandemic (2009-2010), not only for allegedly declaring a pandemic that did not happen, but above all by claims of undue influence of the pharmaceutical industry in its deliberative processes, which has led States to acquire unnecessarily large quantities of vaccines and drugs $7,8,9$.

Recently, during the Ebola epidemic in West Africa, distrust in WHO's work has reached unprecedented levels due to its alleged inability to lead a swift and efficient international response to this sanitary crisis 10,11,12. WHO admitted its own mistakes, and the extreme case of Ebola is now being used to justify proposals and initiatives that might cause an erosion of WHO's competences 13, in favor of unilateral actions from powerful actors whose mission, unlike WHO's mission, is not the protection of public health at the international level. Therefore, in the post-Ebola context, proposals to reform $\mathrm{WHO}$ and demands for more transparency and accountability have escalated.

It is in this context that the new Framework of Engagement with Non-State Actors (FENSA) emerges 14. Although FENSA had a difficult gestation, many see it as a crucial element of WHO's reform 15. At the beginning, this topic appeared in the reform agenda as "participation of non-governmental organizations (NGOs)". According to WHO, "non-State actors are entities that do not belong organically to any State institution, that participate or act in international and national relations, and that have the power to influence and cause change" ${ }^{16}$. Despite the fact that Member States are, according to the Director-General of WHO, the only "shareholders and owners" of the Organization 17, WHO recognizes that "non-State actors play a critical role in supporting WHO's work to fulfill its constitutional mandate" 16.

Over the last four years, the negotiation of FENSA absorbed the debate about the participation of NGOs. Approved on May 28, 2016, at the 69th World Health Assembly - the highest deliberative body of the Organization - FENSA describes itself as a "policy" and as "operational procedures on management of engagement with non-State actors", which applies "at all levels of the Organization" 14. However, FENSA is clearly an international legally binding rule, among other reasons, because it stipulates sanctions, after due process, in case of non-compliance by a non-State actor. For example, in the case of important and intentional cases of non-compliance, the non-State actor concerned should be automatically excluded from other engagements with the institution 14 . In addition, any financial contribution received by WHO that is subsequently discovered to be noncompliant with the terms of FENSA shall be returned to the contributor 14 .

Therefore, the object of the regulation changed from participation to collaboration, and those covered by such regulation extended from just NGOs to other non-State actors, which are now classified into four categories: NGOs, private sector entities, philanthropic foundations, and academic institutions (Figure 1). In addition to establishing a general framework, which applies to the four above mentioned categories, the new instrument dedicates specific regimes to each non-State actor 14.

Although unanimously praised by representatives of Member States, FENSA was received with suspicion by many NGOs, fearful that the new Framework constitutes, in practice, a way of 
Figure 1

Framework of Engagement with Non-State Actors (FENSA): definitions of non-State actors.

\begin{tabular}{|c|c|c|}
\hline Private sector $(\S 10)$ & \multicolumn{2}{|c|}{$\begin{array}{l}\text { - Commercial enterprises, that is to say, businesses that are intended to make a profit for } \\
\text { their owners; } \\
\text { - Entities that represent, or are governed or controlled by, private sector entities, including } \\
\text { international business associations. }\end{array}$} \\
\hline Nongovernmental organizations (§9) & $\begin{array}{l}\text { - Nonprofit entities that operate independently of } \\
\text { governments, free from concerns which are primarily of } \\
\text { a private, commercial or profit-making nature. }\end{array}$ & \multirow{3}{*}{$\begin{array}{l}\text { WHO will determine through its due } \\
\text { diligence if a non-State actor is subject } \\
\text { to the influence of private sector } \\
\text { entities (through financing, participation } \\
\text { in decision-making or otherwise) to the } \\
\text { extent that the non-State actor has to } \\
\text { be considered itself a private sector } \\
\text { entity (\$13). }\end{array}$} \\
\hline Philanthropic foundations (§11) & $\begin{array}{l}\text { - Nonprofit entities whose assets are provided by donors } \\
\text { and whose income is spent on socially useful purposes, } \\
\text { clearly independent from any private sector entity in } \\
\text { their governance and decision-making. }\end{array}$ & \\
\hline Academic institutions ( $\$ 12)$ & $\begin{array}{l}\text { - Entities engaged in the pursuit and dissemination of } \\
\text { knowledge through research, education and training, } \\
\text { including think tanks that are policy-oriented institutions, } \\
\text { as long as they primarily perform research. }\end{array}$ & \\
\hline
\end{tabular}

legitimizing the unwarranted influence of the private sector and of philanthropic foundations in the deliberative process of the Organization 18.

Aiming to fill the gap in the still scarce academic literature on FENSA, this article, after introducing the theoretical framework and methodology of our research, presents the results of the analysis of FENSA in light of the main functions of accountability.

\section{Theoretical framework and methods}

This article discusses a new dimension of a research agenda on Global Health Governance (GHG). The concept of GHG is criticized for its lack of clarity, considering the differences in how public officials and the academia apply the term, and for the lack of critical reflection on its normativity 19. GHG's practices are also particularly condemned due to the lack of transparency and accountability of its main actors (WHO, the World Bank, pharmaceutical industry, and philanthropic foundations) 20. In the last few decades, we have witnessed a remarkable increase of calls for more accountability in the global arena. These calls were triggered by the perceived "challenge of unaccountability" that pervades the legal environment beyond the state 21 . Despite such opacity, there is no doubt about the growing impact of international and transnational decision-making processes on public health in all countries $22,23,24,25$.

The question that guides our investigation is whether FENSA is an appropriate accountability mechanism to meet its announced goals. The answer builds on the results of a previous work on accountability developed by one of the authors in the field of International Legal Theory 26. We understand that the study of FENSA according to this theoretical framework may be an important interdisciplinary contribution to both Public Health and International Relations, as it offers a new tool to critically analyze the collaboration between WHO and non-State actors and to clarify the functions that FENSA might perform.

Accountability connects an agent with power to make decisions (power-holder) to those who suffer the effects or have legitimate interests in these decisions (account-holder). It exists whenever 
the power-holder has the obligation to account and the account-holders are entitled to demand an account for the actions (or inactions) of the power-holder.

From the perspective of accountability, FENSA institutionalizes and regulates the links between: (i) WHO, which is the power-holder, in that it has the constitutional mandate as the directing and coordinating authority on international health work; and (ii) many account-holders, including the non-State actors enumerated by FENSA, but also other actors who might have a legitimate interest in WHO's decisions.

We believe that FENSA aspires to be an accountability mechanism, among other reasons, because WHO presents the new Framework as a response to the lack of transparency regarding its relations with the most powerful actors of the GHG, namely the private sector and philanthropic foundations. This does not mean that the latter cannot also act through other actors, such as States, NGOs, and academic institutions. Such connection can occur either by way of direct financing these entities or by other forms (providing training for specialists, disseminating academic publications, promoting events, mobilizing networks etc.). By regulating the collaboration between WHO and non-State actors in a clearer and more complete way, FENSA might bring limits or even encourage WHO to be more accountable for its actions and decisions in view of the fact that it has adopted: (i) normative parameters against which organizational practices can be collated (Figure 2) and (ii) procedures against which compliance can be monitored and demanded (Figure 2).

It is also assumed that FENSA, by improving and increasing the transparency of the accreditation system of entities interested in collaborating with WHO, will expand the range of non-State actors with whom WHO collaborates and allow the current collaboration with certain actors to be better known and critically analyzed. As a consequence, other actors, who are not beneficiaries of FENSA, such as the media, national or regional parliaments, and independent researchers would have greater access to information on the relationship between WHO and non-State actors.

The appropriateness of the accountability arrangements proposed by FENSA is measured against the four functions that usually justify the demands for more accountability 26 :

- Constitutional, according to which we evaluate the possible checks and balances effect of FENSA, without neglecting WHO's character of absolute intergovernmentalism, i.e., the exclusive competence of Member States to make decisions within WHO;

- Democratic, by which we seek to assess the ability of FENSA to expand the dialogue between different actors;

- Epistemic, which allows us to verify whether FENSA provides the tools for WHO to adopt better decisions, particularly thanks to its collaboration with experts;

- Populist, through which we can check whether FENSA encourages obedience from the actors to whom WHO's decisions are directed by giving the impression of being more transparent and open, legitimizing relations that were until then opaque.

The evaluation of FENSA according to these four functions of accountability is based on extensive documentary research. We examined WHO's documents relating to participation of NGOs and cooperation with non-State actors. We analyzed, in particular, the evolution of different text versions of FENSA over the past two years of negotiations. The research was complemented by a literature review on the reform of WHO, as well as by the coverage on the most active NGOs regarding the negotiations of FENSA, in particular their open letters, opinion articles, and declarations at the World Health Assembly that approved FENSA.

\section{Results and discussion}

The collaboration of WHO with non-State actors is essential to the extent that, according to FENSA, it supports the implementation of WHO's policies and recommendations, as well as the application of its rules and standards. Such importance does not justify, however, a lack of transparency and "due diligence" 14 (art. 4). According to FENSA, due diligence means the measures adopted by WHO to obtain and verify relevant information on a non-State actor and to reach a clear understanding of its profile; while risk assessment refers to the assessment of a specific proposed engagement with that non-State actor (art. 29) (Figure 3). 
Figure 2

Framework of Engagement with Non-State Actors (FENSA): principles, benefits and risks of engagement.

\begin{tabular}{|c|c|}
\hline Principles (§5) & $\begin{array}{l}\text { - Demonstrate a clear benefit to public health; } \\
\text { - } \text { - Respect the intergovernmental nature of WHO and the decision-making authority of Member States as established in the } \\
\text { WHO's Constitution; } \\
\text { - Support and enhance, without compromising, the scientific and evidence-based approach that underpins WHO's work; } \\
\text { - Protect WHO from any undue influence, in particular on the processes in setting and applying policies, norms and } \\
\text { standards, including information gathering, preparation for, elaboration of and the decision on the normative text; } \\
\text { - Not compromise WHO's integrity, independence, credibility and reputation; } \\
\text { - Be effectively managed, including by, where possible avoiding conflict of interest and other forms of risks to WHO; } \\
\text { - Be conducted on the basis of transparency, openness, inclusiveness, accountability, integrity and mutual respect. }\end{array}$ \\
\hline Benefits (§6) & $\begin{array}{l}\text { - Contribution of non-State actors to the work of WHO; } \\
\text { - Influence that WHO can have on non-State actors to enhance their impact on global public health or to influence the } \\
\text { social, economic and environmental determinants of health; } \\
\text { - Influence that WHO can have on non-State actors' compliance with WHO's policies, norms and standards; } \\
\text { - Additional resources non-State actors can contribute to WHO's work; } \\
\text { - Wider dissemination of and adherence by non-State actors to WHO's policies, norms and standards. }\end{array}$ \\
\hline Risks (§7) & $\begin{array}{l}\text { - Conflicts of interest; } \\
\text { - Undue or improper influence exercised by a non-State actor on WHO's work, especially in, but not limited to, policies, } \\
\text { norms and standard setting, including information gathering, preparation for, elaboration of and the decision on the } \\
\text { normative text; } \\
\text { - Negative impact on WHO's integrity, independence, credibility and reputation; and public health mandate; } \\
\text { - Engagement being primarily used to serve the interests of the non-State actor concerned with limited or no benefits for } \\
\text { WHO and public health; } \\
\text { - Engagement conferring an endorsement of the non-State actor's name, brand, product, views or activity; } \\
\text { - Whitewashing of a non-State actor's image through an engagement with WHO; } \\
\text { - Competitive advantage for a non-State actor. }\end{array}$ \\
\hline
\end{tabular}

Therefore, the main objectives of FENSA 14 would be, on the one hand, to strengthen WHO's collaboration with non-State actors "for the benefit and interest of global public health", and on the other hand, to manage potential risks arising from this collaboration, with a view to protecting and preserving the integrity and reputation of the Organization (art. 4).

Among the general principles governing the collaboration between WHO and non-State actors, it is important to highlight transparency, openness, and accountability (art. 5h). The scrutiny of FENSA leaves no doubt, then, that WHO presents it as an accountability mechanism. The question that remains to be answered is whether this new benchmark is an appropriate accountability mechanism, which will be discussed in the light of the aforementioned four functions: constitutional, democratic, epistemic, and populist.

\section{The need for checks and balances}

FENSA sets up two important principles. First, the collaboration between WHO and non-State actors should conform to WHO's Constitution, its mandate and its general program of work (art. 5b). Second, there should be a respect for WHO's intergovernmental nature and the decision-making authority of its Member States (art. 5c). It is undisputed that private entities have achieved such influence on GHG so as to be invited to speak at the opening of the World Health Assembly, as was the case with 

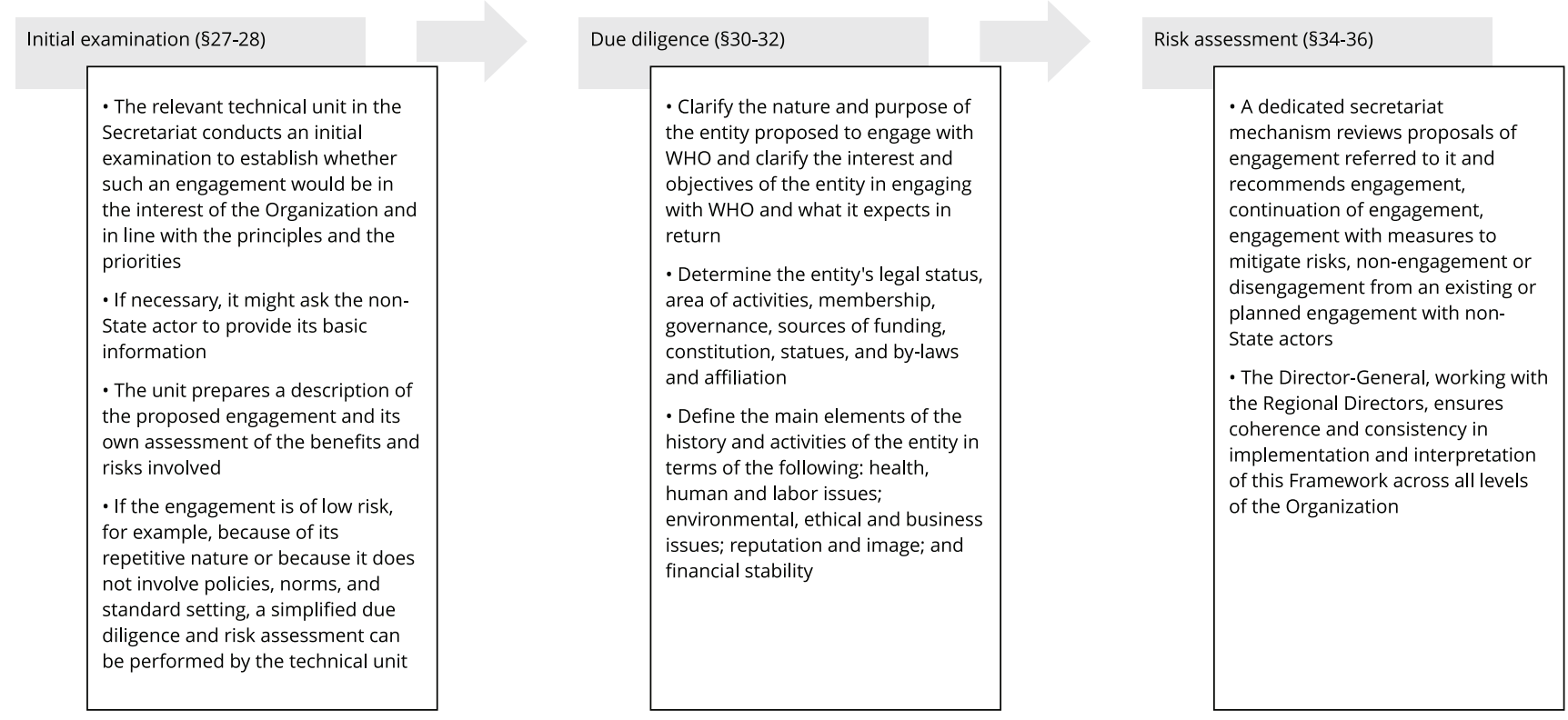

Bill and Melinda Gates Foundation in 2005, 2011, and 2014 27. However, from the legal point of view, the deliberative process of WHO's decision-making bodies includes only the participation of representatives from the States. In practice, however, such formal exclusivity is relativized by both (i) the agenda of private financiers, who are able to influence the definition of WHO's priorities (which tends to favor programs for which funding is not necessarily urgent or of global interest) and (ii) the role of experts, who provide the material substrate for various decisions taken by political authorities (the example are the Committees, which support a declaration of Public Health Emergency of International Concern, such as the association between the Zika virus, microcephaly, and other neurological disorders and which was declared an international emergency in February 2016).

It is worth asking, then, whether FENSA sets up a system of “checks and balances” of WHO's performance. We might recall that FENSA does not prescribe institutional competences to non-State actors nor does it grant them with a "right to participate". Such participation remains at the sole discretion of WHO and it is not even considered a deliberative type of participation. Nevertheless, we believe that, to some extent, FENSA has the potential to increase the capacity of Member States (which already have the power and the right to participate and to vote) and of other GHG actors (who might be covered by FENSA or not) to control WHO's decision-making processes.

A better control of WHO's actions is possible whenever there is an increase of official information on the collaboration with non-State actors. To this end, FENSA establishes an internal control mechanism on the collaboration between WHO's agents and non-State actors, which is accessible to Member States. There is, then, material substrate (by the access of the procedure that decides to initiate or to continue the collaboration) to install an intra-WHO hierarchical control (for example, from the Director-General regarding other work stations) and to allow Member States to question WHO's decision to collaborate with such an actor and whether such collaboration complies with the provisions about risk management and due diligence.

Two limitations of such mechanism should be highlighted. First, FENSA does not enable independent auditors to control the collaboration with non-State actors 28 . Second, the provisions on 
access to information have restrictive interpretations. According to FENSA 14 (art. 38), the "WHO register of non-State actors" is an electronic tool in which the public can access, via Internet, information provided by non-State actors and the description of the engagement WHO maintains with such non-State actors, including information about financial contributions. However, in a footnote, it is stated that the "WHO register" might contain four levels of information: "a publicly available level, a level made available to Member States, a working level for the Secretariat, and a level of confidential and sensitive information accessible to a limited number of individuals within the Secretariat" 14 (art. 38, footnote 2).

On the other hand, it should be noted that FENSA regulates the constitutional competence of WHO (to collaborate with non-State actors) when it stipulates sanctions against non-State actors in the event of non-compliance with its provisions. Non-compliance includes: to delay information or to provide wrong information to the "WHO register of non-State actors"; to use the engagement with WHO for commercial and promotional purposes; and to misuse WHO's name and emblem and to attempt undue influence (art. 69). As for the sanctions, they range from warning to a rejection of renewal of engagement and termination of engagement (art. 70). In addition, any financial contribution that is discovered to be non-compliant with the terms of FENSA shall be returned to the contributor (art. 71). Strangely enough, FENSA does not establish sanctions for WHO's agents who are complicity with non-compliance.

\section{Who has the right to participate?}

Due to the characteristics of the decision-making processes of intergovernmental International Organizations - which is essentially linked to the will of its Member States, such as WHO -, there are significant limits to the participation of civil society. In the context of International Organizations, however, WHO was the pioneer in establishing participatory practices. Since 1946, WHO Constitution allows the Organization to consult and to cooperate with NGOs 1 . Article $18 \mathrm{~h}$ of the same instrument states that NGOs are entitled to participate, without voting rights, in the meetings organized by the Organization. In theory, only NGOs that maintain "official relations" with WHO may take part in the meetings of the decision-making bodies 1 . The Executive Board, after the scrutiny of the Standing Committee on Nongovernmental Organizations, is the actor responsible for admitting such NGOs 29,30 . One of the criteria for being admitted in "official relations" is that such NGOs shall be free from concerns that are primarily of a commercial or profit-making nature 29.

The most recent consolidated list, as of January 2016, computes 206 NGOs in official relations with WHO, and this number comprises a very heterogeneous range of entities 31 . Since 1948, these NGOs are automatically invited to participate at the Organizations' governing bodies 29 . However, information provided by WHO show that the effectiveness of such system is limited 32 . NGOs may only speak after Member States and they have to submit their statements 24 hours in advance. In addition, the system is not effective for WHO Country and Regional levels. The participation rate is low: less than $50 \%$ of the NGOs in "official relations" attend the World Health Assembly, which happens every May, and less than 30\% participate in the January Executive Board sessions.

However, according to WHO, what is striking about the long-term relationship with NGOs is that "the majority of relations are informal" 32 . On the one hand, informality brings some advantages such as speediness and absence of bureaucratic obstacles. On the other, it might increase the discretion to choose partners and thwart the effective control of the decision-making process. Endowed with a complex institutional dynamic and a wide range of duties, including the production of standards that influence health policies around the world, WHO stages conflicts between deeply different political and economic interests. Within WHO, these interests are represented by both Member States (which are themselves strongly pressed by domestic, international and transnational non-State actors) and other agents. Protected by informality, this equation of interests cannot always be seen clearly.

In theory, formal and informal relations are regulated by principles that protect WHO from undue interference. The principles on WHO's relations with NGOs were approved at the first WHA, in 1948, and revised in 1987 29. In 2003, the Director-General sought to reform such principles, but was, ultimately, unsuccessful 33. As for the private sector, in 2000, the Secretariat adopted guidelines to "help WHO staff interact appropriately with commercial enterprises in order to achieve positive outcomes for health" 34 (p. 2). 
When it comes to informal relations, however, it is very difficult for third parties to monitor the effective application of such principles. In 2012, the 65th WHA requested the Director-General to present a draft policy paper on WHO's engagement with NGOs, a draft policy paper on the relationships with private commercial entities, and a report on WHO's hosting arrangements of health partnerships, based largely on the principles of intergovernmentalism and of independence 35 . This process culminated, after several meetings and drafts, in FENSA, which will replace the principles and guidelines mentioned above.

To know whether FENSA does have a democratic function, it is important to ask, first of all, if it was built taking into account the opinion of its recipients. The answer to this question is complicated by the heterogeneity of the interests of actors covered by FENSA.

NGOs, for example, have for years suggested that WHO should adopt a clear definition of conflict of interests 28 . However, various active organizations within WHO have recently demonstrated their disagreement with FENSA. In October 2015, a non-paper from the Secretariat, which anticipated "detrimental consequences" that could ensue from FENSA 36, caused an outrage of over 60 civil society organizations. In a letter sent to the Director-General, such organizations basically protested that the tone of the non-paper could "undermine further strengthening of FENSA" while, in a content-related aspect, they argued that "FENSA provisions on conflicts of interest contain conceptual errors, despite repeated attempts by public interest advocates to highlight these in the governing body debates and in NGO statements" 37.

As for the potential of the democratic function within FENSA, the nature and extent of non-State actors' influence on decision-making processes will hinge on the type of interaction each non-State actor has with WHO, which range from technical collaboration to more direct participation. There remains a difference between actors that maintain "official relations" and those who do not. Official relations are defined as a "privilege". Apparently, the difference between these two categories is the guarantee of participation of the "privileged" in the meetings of the decision-making bodies. As for the other forms of collaboration, FENSA does not contain the "right to participate", having WHO total discretion to formulate invitations.

It is relevant to note that FENSA, in its annexes, adopts specific rules for each non-State actor. At this point, before the effective implementation of FENSA, it is still unclear whether the adoption of specific rules for the private sector and philanthropic foundations increases the control of Member States and other actors on the main donors of WHO or, on the contrary, whether it increases the capacity of the main donors to influence WHO's actions.

\section{Is there an independent expertise?}

As an under-resourced organization, WHO depends on its ingenuity to create mechanisms of information-gathering and knowledge-producing, which are WHO most important roles in GHG. According to FENSA 14, the term "evidence" refers to contributions based on updated information, knowledge of technical issues and review of scientific data, which must be independently analyzed by WHO (art. 18). The production of evidence includes the collection, analysis, and generation of information. The scientific evidence generated from such process should be made publicly available (art. 18).

The evidence established by WHO have immeasurable influence on the formulation of national health policies. But how to ensure that the scientific evidence, as well as WHO's recommendations, are not influenced by the interests of non-State actors with which the Organization collaborates?

FENSA 14 recognizes that WHO faces "a combination of converging and conflicting interests" when engaging with non-State actors (art. 24). The risk of potential conflicts of interest would be the highest when non-State actors' interests, in particular of economic and commercial grounds, are at odds with WHO's public health policies and interests (art. 26). In response to such risk, FENSA offers a controversial concept of conflict of interest, applicable to both specialists who collaborate in any way with WHO, as well as to WHO's employees.

A conflict of interest emerges in situations where there is potential for a secondary interest (for example, an interest in the outcome of WHO's work in a given area) to unduly influence, or where it may be reasonably perceived to unduly influence, the independence or objectivity of professional judgment or actions regarding a primary interest, which is WHO's work (art. 22). This article further 
clarifies that a conflict of interest does not mean that an improper action has actually occurred, but rather the risk of such improper action occurring (art. 22).

In practice, the statements of conflict of interest published by WHO (for example, those relating to members of the Emergency Committees under the International Health Regulations) are quite vague. Despite being ill-defined, these statements allow us to detect a great tolerance regarding the profile of experts recruited. These experts have connections with the private sector, especially in terms of technical training and research funding 25.

On the other hand, FENSA forbids WHO to cooperate with the tobacco and arms industries, but restricts itself to only recommend caution when it comes to cooperation with non-State actors whose policies or activities adversely affect human health and do not meet WHO's policies and standards, in particular those related to noncommunicable diseases and their determinants (art. 45). It is assumed that FENSA refers here to the food industry, which is responsible for the vertiginous worldwide incidence of diseases such as obesity, diabetes, hypertension etc.

FENSA does not apply to WHO's participation in the Codex Alimentarius, which is the most important standard, guideline, and code of practice designed to contribute to the safety, quality, and fairness of the international food trade. In principle, FENSA would also apply to WHO's engagement in external partnerships (art. 49, a, ii). However, a footnote states that the Codex Alimentarius Commission is an intergovernmental body, which is the principal organ of the joint Food and Agriculture Organization of the United Nations (FAO)/WHO food standards program for which the administration is not solely provided by WHO, being supported by subsidiary bodies, including Codex committees, regional coordinating committees and task forces. Therefore, "Meetings of the Commission, Committees, including independent expert committees, and Task Forces are regulated by the Rules of Procedure and other decisions adopted by the Codex Alimentarius Commission" 38, not by FENSA. Although the text of the English version may seem ambiguous, the Spanish version is clear (no están sujetos al marco) 38.

Finally, according to FENSA, WHO should not accept secondments from the private sector (art. 47). However, there are complaints about the systematic recruitment of directors of the Gates Foundation by WHO, which led Dominique Kerouedan 39 (p. 67) to say: "if the world health is now dominated by Bill Gates, then there is no chance that it will be global: his philanthropy does not radiate beyond some infectious diseases", which are those "perceived as threats to others, and preferably for the richest of the planet". It should be mentioned that when talking about WHO reform some authors have even defended that a wide range of functions presently carried out by WHO should be "outsourced" to the Bill and Melinda Gates Foundation, Médicins Sans Frontières, or national regulatory agencies 40.

\section{To legitimize WHO or its donors?}

In our opinion, this situation highlights the populist function as the most important dimension of FENSA ${ }^{14}$. Among its principles are:

The protection of WHO from "undue influence", in particular in the formulation of policies and standards (art. 5e);

The non-compromise of WHO's integrity, independence, credibility, and reputation (5f), so as to avoid conflicts of interest $(5 \mathrm{~g})$.

Incidentally, the word "reputation" appears nine times throughout the text: arts. 4, 5f, 7c, 31, and 72 of the overarching regime; art. 5 of the special regime for NGOs, art. 6 of the regime for academic institutions, art. 5 of the regime for philanthropic foundations, and art.7 of the regime for the private sector. Among the risks posed by the collaboration between WHO and non-State actors, FENSA mentions: the possibility of the collaboration being primarily used to serve the interests of the nonState actor and not WHO's interests (7d); the possibility of the collaboration endorsing the non-State actor's name, brand, and product (7e); the possibility of the collaboration creating a "competitive advantage" for non-State actors $(7 \mathrm{~g})$; and the possibility of the collaboration enhancing the non-State actors' image (7f).

WHO aims to convince the public opinion and a complex set of actors, including its Member States, that its relations with non-State actors are clearly framed. On the other hand, it also offers its donors, which are now mainly the private sector and the philanthropic foundations, the institutionalization of their cooperation. 
In order not to create frictions with the private sector, instead of addressing the larger issues of governing the activities of industries, FENSA focuses narrowly on the issues of risk assessment and management for WHO itself when engaging with the private sector ${ }^{15}$. Even if the provisions about due diligence to protect WHO are well implemented, they will not necessarily translate into improved corporate practices at global and national levels that will act to promote and protect the health of their consumers. Rather than placing WHO within the political economy of GHG, FENSA seems to be a reform that gets closer to proposals that understand WHO as a purely technical body: setting standards, collecting, analyzing, and publishing data etc. 41

That is why some NGOs, which are also the addressees of FENSA, fear that FENSA is a sort of "Trojan horse" 37, that would "set the fox to guard the henhouse" 42, by legitimizing new channels of undue industry influence, including through staff secondment, pro-bono work, participation in meetings and 'support' to policy-making 43. Is FENSA, then, a fund-raising instrument or a policy to safeguard WHO's capacity to fulfill its mandate? 44.

By analyzing the manifestations of NGOs in official relations with WHO during the World Health Assembly that approved FENSA 44, we found out that, at least initially, FENSA did not seem to have produced the desired effect. According to International Baby Food Action Network (IBFAN), FENSA, in its overarching section, puts private sector entities on an equal footing with other non-State actors, failing to recognize their profoundly different nature and roles. IBFAN considers that the principle of "inclusiveness", when applied to transnational corporations, business associations and philanthropic foundations reinforces the framing of public health problems and solutions that favor their interests and agendas, and denounces that "the failure of the resolution to call for development of comprehensive conflicts of interest safeguards is perplexing". International Diabetes Federation (IDF) highlights the lack of clarity of FENSA and demands a better control of the food industry.

Conversely, the International Federation of Pharmaceutical Manufacturers and Associations (IFPMA) considers that FENSA still appears to be restrictive in a number of areas that could hamper non-State actors in their ability to fully contribute to global health outcomes. It calls Member States to consider a periodic review of FENSA so as to ensure its relevance and to amend it as necessary if it becomes a barrier, rather than a facilitator for WHO to acheive its objectives. Finally, IFPMA demands the introduction of flexibilities, such as a phased approach to mitigate unintended consequences as well as exceptions that emergency situations dictate.

The first results of our research indicate, therefore, the risk of the populist function prevailing at the expense of the other three functions that FENSA could play as an accountability mechanism. It is quite clear that the adoption of FENSA aspired to improve WHO's image and to increase its ability to obtain funding, but it seems much less clear that FENSA is able to be effective in such tasks. At the moment, it is crucial to monitor the implementation of FENSA and to complement this article with an empirical research to be carried out with the main actors of the regulation about the collaboration between WHO and non-State actors. In any case, the study of FENSA sheds light on the limits and challenges of the ongoing reform of WHO.

\section{Contributors}

The two authors contributed equally to all stages of the study.

\section{Acknowledgments}

D. H. Rached is postdoctoral researcher supported bu the São Paulo State Research Foundation (FAPESP) and, D. F. L. Ventura is a researcher productive fellow from the Brazilian National Research Council (CNPq). The authors gratefully acknowledge the two agencies for the scholarships that allowed this research. 


\section{References}

1. World Health Organization. Constitution of the World Health Organization. 45th Ed. http://www.who.int/governance/eb/ who_constitution_en.pdf (accessed on 02/ Jun/2016).

2. World Health Organization. Investing in the World's Health Organization taking steps towards a fully-funded Programme Budget 2016-17. Geneva: World Health Organization; 2015.

3. World Health Organization. Top 20 voluntary contributors 2012-2013. http://www.who.int/ about/funding/top20.pdf?ua=1 (accessed on 02/Jun/2016).

4. Chan M. WHO Director-General opening remarks at 2015 financing dialogue. http:// www.who.int/dg/speeches/2015/financingdialogue/en/ (accessed on 02/Jun/2016).

5. Kimberley M. Privatized Ebola: the Bill and Melinda Gates Foundation is the World Health Organization's boss, not governments. Global Research 2014; 15 oct. http:// www.globalresearch.ca/privatized-ebola-thebill-and-melinda-gates-foundation-is-theworld-health-organizations-boss-not-governments/5408056 (accessed on 02/Jun/2016).

6. A plan to protect the world - and save WHO. Lancet 2015; 386:103.

7. Cohen D, Carter P. WHO and the pandemic flu “conspiracies". BMJ 2010; 340:c2912.

8. Parliamentary Assembly, Council of Europe. Resolution 1,749 (2010). Handling of the H1N1 pandemic: more transparency needed. Paris: Council of Europe; 2010.

9. Godlee F. WHO must act now to restore its credibility, and Europe should legislate. BMJ 2010; 340:c2947.

10. World Health Organization. Report of the Ebola Interim Assessment Panel. http://www. who.int/csr/resources/publications/ebola/ report-by-panel.pdf?ua $=1$ (accessed on 02/ Jun/2016).

11. Médecins Sans Frontières. Pushed to the limit and beyond: a year into the largest ever Ebola outbreak. http://www.msf.org/sites/msf.org/ files/msf1yearebolareport_en_230315.pdf (accessed on 11/Jun/2016).

12. Ebola: a failure of international collective action. Lancet 2014; 384:637.
13. Kamradt-Scott A, Harman S, Nunes J, RoemerMahler A, Wenham C. WHO must remain a strong global health leader post Ebola. Lancet 2015; 385:111.

14. World Health Organization. Agenda item 11.3. Sixty-ninth World Health Assembly. Framework of engagement with non-State actors. Geneva: World Health Organization; 2016.

15. Buse K, Hawkes S. Sitting on the FENSA: WHO engagement with industry. Lancet 2016; 388:446-7.

16. World Health Organization. WHO governance reform. Report by the Secretariat. Geneva: World Health Organization; 2013.

17. Canh M. Opening remarks at a consultation on WHO engagement with nongovernmental organizations. http://www. who.int/dg/ speeches/2012/consultation_20121018/en/ index.html (accessed on 02/Jun/2016).

18. Gulland A. WHO open to "lobbying" by business. BMJ 2016; 353:i3134.

19. Lee K, Kamradt-Scott A. The multiple meanings of global health governance: a call for conceptual clarity. Global Health 2014; 10:28.

20. Ottersen OP, Dasgupta J, Blouin C, Buss P, Chongsuvivatwong V, Frenk J, et al. The political origins of health inequity: prospects for change. Lancet 2014; 383:630-67.

21. Najam A, Halle M. Global environmental governance: the challenge of accountability. Boston: Frederick S. Pardee Center for the Study of the Longer-Range Future, Boston University; 2010. (Sustainable Development Insights, 5).

22. Kerouedan D, Brunet-Jailly J. Santé mondiale. Paris: Presses de Sciences Po; 2016.

23. Biehl J, Petryna A. Critical global health. In: Biehl J, Petryna A, editors. When people come first. Princeton: Princeton University Press; 2013. p. 1-20.

24. Gostin L. Global health law. Cambridge: Harvard University Press; 2014.

25. Ventura D. Direito e saúde global - o caso da pandemia de gripe AH1N1. São Paulo: Expressão Popular; 2013. 
26. Rached D. The concept(s) of accountability: form in search of substance. Leiden Journal of International Law 2016; 29:317-42.

27. World Health Organization. Sixty-seventh World Health Assembly. Agenda item 4. Address by Melinda Gates, Bill \& Melinda Gates Foundation. Geneva: World Health Organization; 2014.

28. Poulain M. Les négociations du droit de la santé: l'OMS à la croisée des chemins. In: Cadeau E, Mondielli E, Vialla F, editors. Mélanges en l'honneur de Michel Bélanger. Bordeaux: LEH Éditions; 2015. p. 101-16.

29. World Health Organization. Principles governing relations between the WHO and NGOs. Geneva: World Health Organization; 1987.

30. World Health Organization. EB138/48 Reports of committees of the Executive Board Standing Committee on Nongovernmental Organizations. Geneva: World Health Organization; 2016.

31. World Health Organization. List of 206 nongovernmental organizations in official relations with WHO reflecting decisions of EB138. Geneva: World Health Organization; 2016.

32. World Health Organization. Towards a new policy of WHO engagement with NGOs consultation with NGOs. http://www.who. int/about/who_reform/documents/Presentation_NGO_18Oct2012.pdf (accessed on 02/ Jun/2016).

33. World Health Organization. Policy for relations with nongovernmental organizations. Report by the Director-General. Geneva: World Health Organization; 2002.

34. World Health Organization. Guidelines on working with the private sector to achieve health outcomes. Report by the Secretariat. Geneva: World Health Organization; 2000.

35. World Health Organization. Sixty-fifth World Health Assembly. Decisions and list of resolutions. Geneva: World Healthn Organization; 2012.

36. World Health Organization. Implication of implementing the FENSA. Geneva: World Health Organization; 2015.

37. Arla M. WHO: civil society protest over undermining of current negotiation on FENSA. http://www.twn.my/title2/unsd/2015/unsd151006.htm (accessed on 11/Jun/2016).
38. Organización Mundial de la Salud. 69a Asamblea Mundial de la Salud. Marco para la colaboración con agentes no estatales. Geneva: Organización Mundial de la Salud; 2016.

39. Kerouedan D. Segurança ou insegurança da saúde mundial na África? Mais saúde parcial do que saúde global. Lua Nova 2016; (98):4776.

40. Negin J, Dhillon RS. Outsourcing: how to reform WHO for the 21st century. BMJ Global Health 2016; 1:e000047.

41. People's Health Movement. Ignoring the political economy of global health governance in considering WHO's shortcomings obscures major threats to health equity. A recent proposal to 'outsource' WHO functions illustrates. http://www.phmovement.org/sites/www. phmovement.org/files/WHO\%20outsourcing. pdf (accessed on 11/Jun/2016).

42. Gupta A, Lhotská L. A fox building a chicken coop? WHO reform: 'health for all', or more corporate influence? http://www.policyforum. net/a-fox-building-a-chicken-coop/ (accessed on 11/Jun/2016).

43. Center for Science in the Public Interest. Open letter to members of the 138th EB/WHO: civil society has no confidence in the stalled Framework for Engagement with Non State Actors process. http://cspinet.org/canada/pdf/civil_ society_open_letter.jan25-2016.pdf (accessed on 02/Jun/2016).

44. World Health Organization. Statements by NGOs in official relations with WHO at the WHO governing body meetings. Sixty-ninth World Health Assembly (A69/1). https://apps. who.int/ngostatements/meetingoutline/ 6 (accessed on 12/Jun/2016). 


\section{Resumo}

A $O$ artigo investiga as origens e o conteúdo da Estrutura de Colaboração com Intervenientes Não Estatais (FENSA, em inglês) da Organização Mundial da Saúde (OMS), aprovada em 28 de maio de 2016 pela 69a Assembleia Mundial da Saúde, e que define regras distintas para quatro categorias de atores: organizações não governamentais (ONGs), entidades do setor privado, fundações filantrópicas e instituições acadêmicas. $O$ estudo aplicou os achados da Teoria do Direito Internacional e recorreu a uma extensa pesquisa documental para determinar se a FENSA é um mecanismo apropriado de accountability de acordo com quatro funções de responsabilização: constitucional, democrática, epistêmica e populista. $O$ artigo conclui que há um risco de prevalência da função populista com detrimento do potencial de accountability pelo uso melhor das outras três funções de accountability.

Saúde Global; Responsabilidade Legal; Direito Internacional

\section{Resumen}

El artículo examina los orígenes y el contenido del Marco de Colaboración con Actores no Estatales (FENSA, en inglés) de la Organización Mundial de la Salud (OMS), aprobado el 28 de mayo de 2016 en la 69a Asamblea Mundial de la Salud, que estableció diferentes reglas de colaboración para cuatro categorías de actores: organizaciones no gubernamentales (ONG), entidades del sector privado, fundaciones filantrópicas e instituciones académicas. Aplicando los hallazgos de la Teoría Legal Internacional y basándonos en una extensa investigación documental, buscamos determinar si FENSA es un mecanismo apropiado de rendición de cuentas según cuatro funciones de rendición de cuentas: constitucional, democrática, epistémica y populista. El artículo concluye que existe el riesgo de que la función populista se mantenga a expensas del potencial de rendición de cuentas que podría derivarse del mejor uso de las otras tres funciones de rendición de cuentas.

Salud Global; Responsabilidad Legal;

Derecho Internacional
Submitted on 13/Jun/2016

Final version resubmitted on 24/Oct/2016

Approved on 06/Jan/2017 